disease, rampant in their homeland and relatively frequent in African. troops in the Middle East, fails frequently to respond to routine sulphapyridine treatment. The reason for this seems to be that sulphapyridine-resistant strains have been developed amongst these people. The sale of sulpha-drugs is unrestricted in: East Africa, and probably every sufferer from gonorrhoea has tried once or twice to cure his disease with the famous M. \& B. 693 . The outcome of this enlightenment of the African negro is, of course, that not only he fails to cure his gonorrhoea because of insufficient treatment, but also makes this task more difficult for the V.D. specialist whom he consults sooner or later. A similar state of affairs has been reported from French North Africa.

The possibility suggests itself of sulphapyridine-resistant strains of Koch-Weeks bacilli being harboured by carriers who themselves have only a mild chronic conjunctivitis but are in a position to infect others with it. This infection with a sulphapyridine-resistant strain would explain the failure of the otherwise most reliable treatment with sulphapyridine.

It might be possible to prove this hypothesis with bacteriological tests. The conditions in an isolated military hospital make this unfortunately, impossible. Ophthalmologists in a most favourable position might have the opportunity to do so if they come across similar cases.

\title{
POSTERIOR UVEITIS IN A CASE OF SARCOIDOSIS*
} BY

\author{
Frank R. NeUbert \\ LONDON
}

A considerable literature on the syndrome of uveo-parotid fever, originally described by Heerfordt, emphasises the frequent occurrence of this disease, the widespread nature of its manifestations, an apparent difficulty in the diagnosis of some cases, and a certain lack of agreement among those writers who endeavour to designate the responsible agent.

A bacillus, allied to that of tubercle, is usually indicted, which shows a predilection for certain tissues of which the uvea, parotid gland, lung, skin and intestinal canal, appear to be sites of election.

The case under consideration is of exceptional interest in-as-much as the abdominal picture is probably unique and I am unable to find. any published report of a similar condition in the eye.

\footnotetext{
- Received for publication, September 9, 1946.
} 
The literature shows that there is little specific reference to involvement of the cornea. Keratitis (when present), is said to be interstitial in character, as in the present case, affecting the lower part of the cornea first. Increase in the intra-ocular tension may produce an oedema which obscures it.

Iritis is the most common ophthalmological manifestation and two types have been described.

(a) Benign serous, which shows slight ciliary injection, fine posterior corneal precipitates, and a moderate number of cells in the aqueous.

(b) Nodular type which is'extensive and accompanied by marked ciliary injection, oedema of the cornea, larger and more numerous posterior corneal precipitates, and many cells in the aqueous.

Opinions regarding implication of the posterior uvea and retina vary. Levitt states that it has been reported only by thirteen writers, and King states that, except in a case reported in a personal communication by Reis and Rothfeld, he is unable to find in the literature any case of involvement of the choroid or retina. After evidencing the extreme rarity of sarcoid as a cause of local chorioretinitis, he suggests that it should be regarded as a possible cause in cases in which tuberculin tests are negative and syphilis has been negated. Berg states that choroiditis may occur.

Verhoeff found that in all cases of localized chorio-retinitis in an active stage, in which he examined the eyes histologically, the lesions were characteristic of tubercle. The chief features being an accumulation of epithelioid cells interspersed with a few giant cells and surrounded by a sparse infiltration of lymphocytes, but without necrosis or sclerosis (Duke-Elder).

Duke-Elder states that occasionally the posterior segment is affected also and whitish-yellow masses of histologically typical sarcoid structure may be scattered over the fundus. Levitt apparently considers this to be a periphlebitis, describing yellowish masses in the fundus with a tendency toward perivascular situation. Walsh reports one case showing numerous superficial discrete white spots in the paramacular area and normal vessels.

Reis, Rothfeld and others report that papilloedema, followed by optic atrophy due to involvement of the optic nerve may also occur.

Longcope and others state that the disease occurs often without attendant abnormalities of the skin.

In the series of cases of "Chronic Iridocyclitis and Tuberculosis" reported by Brooks, Juler and Williams, six had uveo-parotitis. Three of these showed a cutaneous tuberculide, maculo-erythematous in type, and three had no skin lesion, as in the case under discussion.

The literature contains only references to posterior uveitis in sarcoidosis and this is apparently the first case to be described and 
illustrated. The history and clinical findings are therefore of considerable interest.

\section{Case history}

1. At the age of two years a radical mastoidectomy was performed for chronic mastoid suppuration. Nothing exceptional was noted in the hospital report.

2. At the age of seven he had malaria whilst living in India.

3. At the age of twenty-four he states that vision deteriorated rapidly after looking at a solar eclipse with the naked eyes. The vision was found to be :-R.E. 6/12, L.E. 2/60.

Both fundi showed coarse disseminated choroidal scarring, with some fresh patches, and slit-lamp examination showed interstitial scarring and cells in the vitreous.

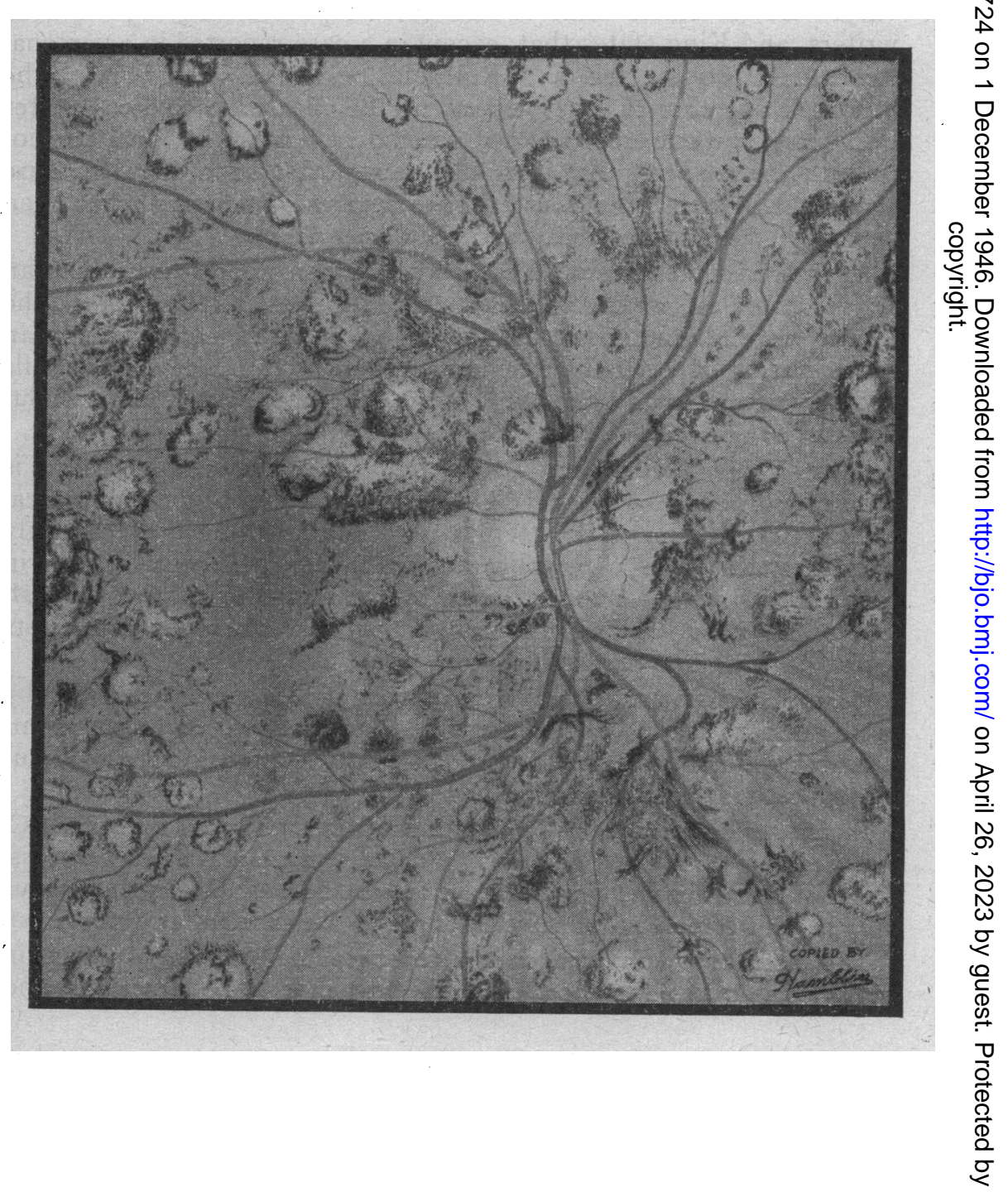




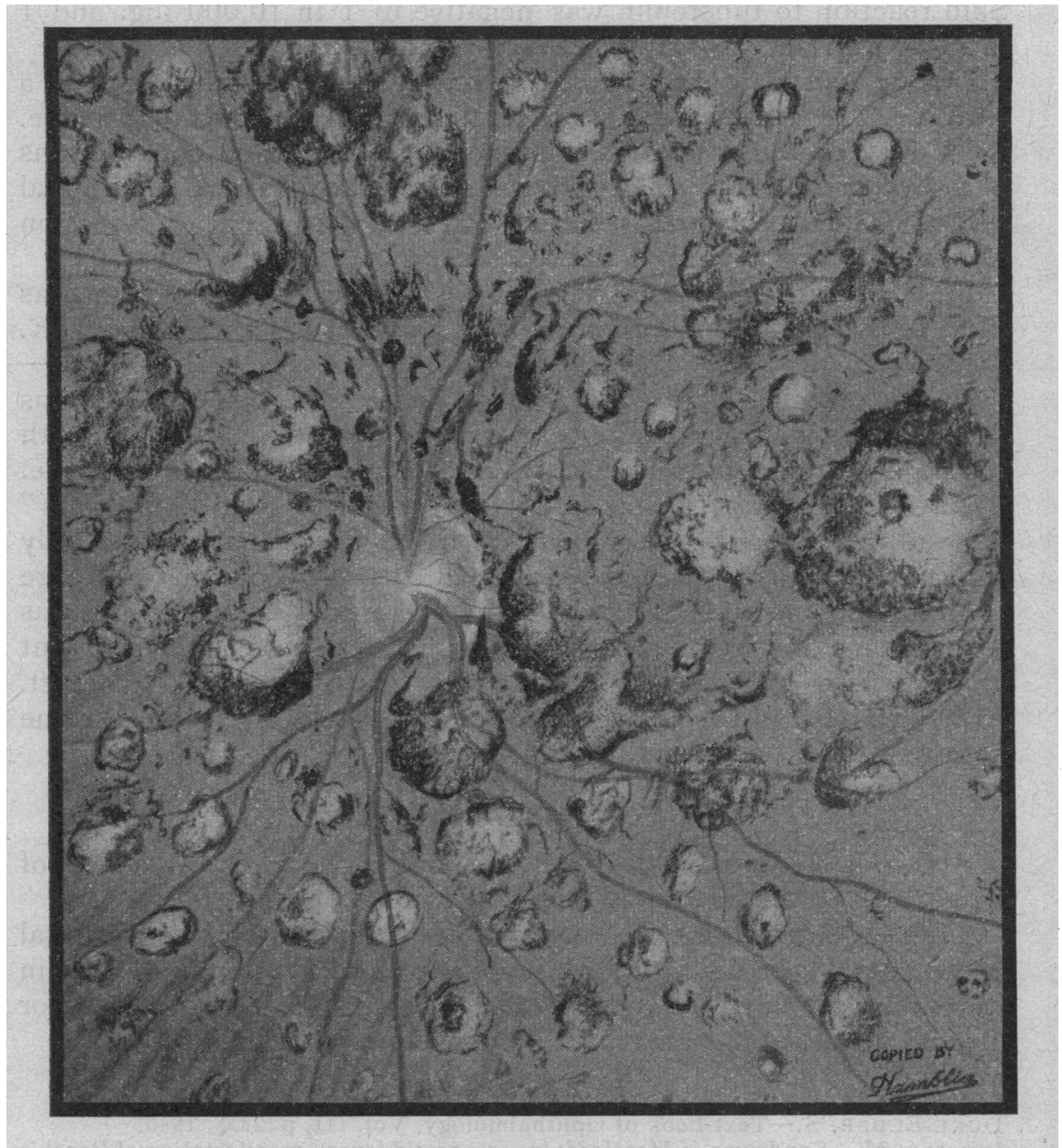

Wassermann reaction was performed twice, and was negative.

Dental X-Ray was also negative, and an otological examination, on account of a history of aural discharge, disclosed merely the scar of a mastoid operation.

The patient was treated with mercury and potassium iodide and some months later vision was improved to,

R.E. $6 / 9$ (with $-0.75 \mathrm{sph}$ ) and L.E. 6/36.

4. In 1941 (aged 29 years) after severe overwork during the air raids on London he collapsed with a bad cough and loss of weight.

Tuberculosis was diagnosed, and he spent five months in a sanatorium. Although the radiogram of the chest was typical of advanced miliary tubercle, the blood sedimentation rate remained at about 7 and the patient's general condition commenced to improve. 
Skin reaction to tuberculin was negative to 1 in $10,000 \mathrm{mg}$. and 1 in $1,000 \mathrm{mg}$. but strongly positive to 1 in $100 \mathrm{mg}$.

During this time he had abdominal symptoms and developed a swelling. A tentative diagnosis of chronic appendicitis was made. An X-Ray examination of the intestinal tract showed constrictions of the caecum with a well-marked "string-sign," typical of regional ileitis. The caecum was resected and a microscopical examination of a section was typical of sarcoidosis.

5. General health improved and in August, 1943, his vision was R.E. 6/24, L.E. $6 / 24$, correcting with glasses to R.E. $6 / 6$ and L.E. $6 / 12$.

At the examination in 1943, and again in 1944, when the fundus drawing was made, no evidence of anterior uveitis could be seen with the corneal loupe, but microscopic examination could not be made.

The fundus changes were not quite typical of "old choroiditis" none of the fibrosed areas showed a glistening white sclera and only the small peripheral ones appeared whitish. The number and size of the lesions decreased centrifugally. The scattered pigment was a deep sepia and was punctate in form. On two areas this pigment took the form of "wheat-sheafs" which I have attempted to depict. Although most of the pigmentation was beneath the vessels, some appeared to be over them.

\section{Conclusion}

A case is reported of disseminated retino-choroiditis in a case of sarcoidosis of the lungs and alimentary canal.

I am indebted to the Secretary of the Manchester Ear Hospital for tracing a case history of 30 years ago; to Dr. Werner of Dublin for particulars from his father's case histories; to Dr. Morland for clinical details of the chest and abdominal condition.

\section{BIBLIOGRAPHY}

DUKE-ELDER, S.-Text-book of Ophthalmology, Vol. III, p. 2358, 1940.

JERSILD, M.-Syndrome of Heerfordt (uveo-parotid fever), manifestation of Boeck's sarcoid Acta Med. Scand., Vol. XCVII, pp. 322-328, 1938.

KEMP, R.-Note on chronic irido-cyclitis, with special reference to sarcoidosis of Boeck. Brit. Jl. Ophthal., Vol. XXIII, pp. 455-460, 1939.

KING, M. J.-Ocular lesions of Boeck's sarcoid. Trans. Amer. Ophthal. Soc., Vol. XXXVII, pp. 422-458, 1939.

KINDT, P.-Three cases of nodular iritis (iritis Boeck?). Acta Ophthal., Kbh., Vol. XVIII, pp. 38-50, 1940.

LEvitT, J. M.-Boeck's sarcoid with ocular localization; survey of literature and report of case. Arch. Ophthal., Chicago, Vol. XXVI, pp. 358-388, (Sept.) correction p. 175 (Oct.). 1941.

PoE, D. L.- Sarcoid of external ear. Ann. Otol., etc., St. Louis, Vol. XLIX, pp. 771-775, (Sept.). 1940.

WAGENER, H. P.-Ocular lesions in sarcoidosis of Boeck. Amer.Jl. Med. Science, Vol. CCIII, pp. 300-309. 1942.

WALSH, F. B.-Ocular importance of sarcoid; its relation to uveoparotid fever. Arch. Ophthal., Chicago, Vol. XXI, pp. 421-438. 1939.

WyскнAм, W. D., JULER. F. A., Williams, E. R.-On the relationship between chronic iridocyclitis and tuberculosis, and the apptopriate therapy. Brit. Jl. Ophthal., (July). 1940. 